\title{
Polish Vegetation Database
}

\author{
Zygmunt Kacki \& Michal Sliwinski
}

\begin{abstract}
The Polish Vegetation Database (GIVD ID EU-PL-001) was created in 2007 at the Department of Biodiversity and Plant Cover Protection, University of Wroclaw. Its aim is to collect all the phytosociological data from the territory of Poland. The database includes mainly vegetation records collected during the last century using the Central European phytosociological method. The sources of the Polish Vegetation Database are mainly published records from regional studies carried out in the territory of Poland. The database also contains unpublished data, mainly from South-western Poland. The largest group of data represents the vegetation of dry and wet grasslands, $40.6 \%$ of the total sources of the database, followed by forest and shrub communities (25.6\%), anthropogenic vegetation $(24.4 \%)$, water and peat bogs $(8.6 \%)$, and other types of vegetation $(0.8 \%)$. The database aims to support the regional and national synthesis for the classification of vegetation, and studies of biodiversity and vegetation transformation in the Polish plant communities. Data collected in the database is also an important source of information about the distribution of plant communities and valuable habitats of the Natura 2000 Project. Information stored in the database is the basis for assessing the habitat preferences and large-scale patterns of plant species richness or geographical distribution. It will also become the basis for testing new research methods and techniques used in the nature conservation and monitoring of environmental changes.
\end{abstract}

Keywords: plant community; phytosociological record; Poland; relevé.

GIVD Database ID: EU-PL-001

Last update: $2012-07-20$

\section{Polish Vegetation Database}

Scope: The aim of the Polish Vegetation Database is to gather all phytosociological relevés from the territory of Poland.

Status: completed and continuing

Period: 1923-2011

Database manager(s): Zygmunt Kacki (kackiz@biol.uni.wroc.pl)

Owner: Faculty of Biological Sciences, University of Wroclaw

Web address: http://www.synbiot.uni.wroc.pl

Availability: free upon request

Online upload: no

Online search: no

Database format(s): TURBOVEG

Export format(s): TURBOVEG, Excel, CSV file, plain text file

Publication: Kacki Z., Sliwinski M. 2012. The Polish Vegetation Database: structure, resources and development. - Acta Soc. Bot. Pol. 81(2):X-X. Plot type(s): normal plots

Non-overlapping plots: 44,348

Plot-size range: $0.1-5,000 \mathrm{~m}^{2}$

Total plot observations: $\mathbf{4 4 , 3 4 8}$

Estimate of existing plots: 180,000

Completeness: $25 \%$

Number of sources: 355

Valid taxa: [NA]

Countries: PL: 100.0\%

Forest: [NA] - Non-forest: [NA]

Guilds: all vascular plants: $100 \%$; bryophytes (terricolous or aquatic): $30 \%$; lichens (terricolous or aquatic): $2 \%$

Environmental data: altitude: $13 \%$; slope aspect: $22 \%$; slope inclination: $22 \%$

Performance measure(s): cover: $100 \%$

Geographic localisation: GPS coordinates (precision $25 \mathrm{~m}$ or less): $2 \%$; point coordinates less precise than GPS, up to $1 \mathrm{~km}$ : $76 \%$; political units or only on a coarser scale (>10 km): $22 \%$

Sampling periods: 1920-1929: 1.0\%; 1950-1959: 3.0\%; 1960-1969: 9.0\%; 1970-1979: 17.0\%; 1980-1989: 16.0\%; 1990-1999: 21.0\%; 2000-2009: 22.0\%; 2010-2019: 2.0\%; unknown: $9.0 \%$

Information as of 2012-07-12; further details and future updates available from http://www.givd.info/ID/EU-PL-001

Zygmunt Kacki* (kackiz@biol.uni.wroc.pl), Michal Sliwinski (synbiot@biol.uni.wroc.pl)

Department of Biodiversity and Plant Cover Protection, Faculty of Biological Sciences, University of Wroclaw , Kanonia 6/8, 50-328

Wroclaw, POLAND

*Corresponding author 